SEDIMENTARY DEFOSITS--AIluvium, loess (Palouse Formation), glaciolucustrine deposits (Including the Touchet beds of Flint, 1938), and older Pleistocene fluvial and lacustrine deposits of Ringold Formation. The lower part of the Ringold may be as old as Pliocene (Brom and McConiga, 1960) but is not exposed in the map area. Mapped only. where important bedrock relations are obscured. Particularly large unmapped areas of Palouse Formation occur in northeast and southcentral parts of area SAUULN MUUNIALNS BASALT

LONER MONORENTAL MEMBER--Essentially aphyItc basalt flow that partly filled. canyon of the ancestral Snare River. Remnants mapped between Lewiston Basin and Devils Canyon. Maxdmum preserved thickness is $60 \mathrm{~m}$, average is about $25 \mathrm{~m}$. Erupted from unkiom location, probably out of nap area in the drainage of the Clearwater or Snake Rivers (Swanson and others, 1975a). Proposed correlation of member with dike in Lewiston Basin (Camp, 1976) now considered incorrect. Stratigraphically youngest-known flow of Columbia River Basalt iroup; K-Ar age is about 6 m.y. (NcKee and others, 1977). Unit includes fluvial gravel and sand beneath flow in places, such as at type locallty at Lower Honumental Dam. Normal paleomagnetic polarity

ICE YEFBOR MEMBER-Basalt flows, minor tephra and thin dikes along a rorth-northwest trending inear vent system (Swanson and others, 1975b) in restern part of map area. Iess than $30 \mathrm{~m}$ thick in most places. DIvided into three informal nap units, all of which have K-Ar ages of : about 8.5 m.y. (Hckee and others, 1977), on the basis of chemistry. petrography, paleonagnetic polarity, and observed stratigraphic sequence. Plagloclase phenocrysts commonly appear more tabular. (needlelike in cross section) than in other Saddle Mountains flows

Flows, minor tephra and dires of Ice Harbor 2 chemical type (Wright and others, 1973; Helz and others, 197_). Characterized petrographically by scattered phenocrysts of plagloclase, olivine, and magnetite generally less than 5 in in diameter. Normal paleomagnetic polarity. Overlies unt $T 1$, downstrean from Ice Harber Dam. In addition to. dikes listed by Swanson and others (1975b, table 2), a 7 m-wide compound dike consisting of five thin dikes of Ice Harber 2 chemical type intrudes the Umatilla Member in a shallow graben too narrow to map $2 \mathrm{~km}$ sest of Reese along the Walla Walla River

Fows, minor tephra, and thin dikes of Ice Harber 1 chenical type (Hight and others, 1973), Including the "upper" Ice Harber 1 unit of Helz and others (197_.). Characterlzed petrographically by sparse to abundant phenocrjsts and glomerophyric clots of augite, plagloclase, and olivine. Some clots are $2 \mathrm{~cm}$ or more in dianeter. Reversed paleomagnetic polarity. Unit locally includes reakly Iithified fluvial arkosic sand and gravel below flow, as in channel filling on top of bluff forming west side of Wallula Gap. Stratigraphic zelation to unit $\mathrm{Tib}$ unsure; considered younger on besis of general field relations south of Eltopia, but part or all of unit could be coeval or older than unit Tib

LIBPARY

NOTE: This report is prel iminary and has not been edited or reviewed for conformit with U.S. Geological Survey standards and nomenclatiure. Most geologic nomen clature used or changed herein will be adopted or amended for USGS usage by D. A. Swanson and others in a forthcoming USGS Bulletin. (Changes in Strati-. graphic Nomenclature series). 
Flows, minor tephra, and thin dikes of Basin Clty chentcal type (Helz and others, 197_). Characterized petrosfaphically by phenocrysts of plagloclase (generaily less than $1 \mathrm{cn} \mathrm{in} \mathrm{width)} \mathrm{and} \mathrm{olivine,} \mathrm{with} \mathrm{no}$ clinopyroxene. Nornal paleonagnetic polarity. Occurs in and along a narrow Eraben fron north end of outcrop belt to near Eltopia, as flows of small lateral extent south of Eltopia, and as thin dikes near Ice Harbor Dan.

FLO:SS OF BUFORD CRDEK-- Basalt flow or flows overlying the Elephant Mountain Fenber and older rociss in southeast part of area. Includes the Buford flow of Walter (1973). Sparse small plagioclase phenocrysts. Generally less than $20 \mathrm{~m}$ thick. Unit includes underlying poorly consolidated tuffaceous sandstone, siltstons, and shale ten or rore meters thick in drainage of Grande londe River. Normal paleomagnetic polardty

Fo\%Oin joigen--Slightly phyric basalt flor of Porona chenical type (uright ard othere, 1973). In places, flow nay be subdivicisd into two units, bit these units are not tracsible far and presumably ropresent gishes of ore eruptive event. Characterized petrosiaphically by small phenocrysts of flasiociase (generally less then $5 \mathrm{~mm}$ long), clinopjroxere, and clivin.e. Hodal analyses are distinctive by low plagloclase/pyroxene ratios (Schilincke, 10;67a). Plaricclase phenocrysts comonly have wedgeshapsd agpearance. Locally, as in quamy on east side of Devils Canyon, flon contaj:s lares clots (up to $10 \mathrm{~cm}$ oi nore across) of plagioclase, pyroxene (incluisng very rare lypersthone), and olivine thought to heve forned auring crystellivation aftor eruption. liember occurs in nearly so remianis of an intracanjon flow along an ancestral snake River Canjon from the Ieviston Eusin to Novils Canjon, and as mnce roilly shectliks flow elsewnire. Souree wis pesumably east or southeast of map area, and lava flowed down the ancestiat snake until. 
debouching from the wouth of the caryon. in the vicinity of Old Masd. Coulee (T. 13 H.,.K. 31 E.) into a broad basin. An aeromagnetic anonaly defines the course of the flow fron Devils Canyon to Old Mald Coulee (Swanson ara others, 197.). Maximum preserved thickness is $110 \mathrm{~m}$ in an intracanjon rennent near the mouth of the Tucannon River; average thickress outside of canyon is about $30 \mathrm{n}$. Reversed paleomagnetic polarity. K-Ar age is about $12 \mathrm{~m} . \mathrm{y}$. (NcKee and others, 1977). Intrecanjon rennants in the Lehsston Basin generally correlate with the lower intracanyon flos of Luphex and Harren (1942). Henber locally includes an lide:rlying distinctive vitric tuff (Schmincke, 1967b) and tuffaceous siltstone. A peperite is conmoniy developed where the flow ploughed into the vitric tufi near the flow margin, as alons Crab Creek in T. 16 H., R. $28 \mathrm{~F}$. and the Snake River in T. $9 \mathrm{~N} ., \mathrm{R} .32 \mathrm{E}$.

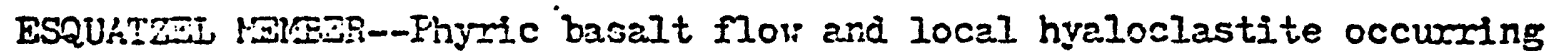
chiefly as rennants of an jntracanyon flow in Esquatzel Colilee and alor: the ansestral Snake River $C_{a n y o n}$ fion Devils Canyon upstrean to the routh of liew Yor: Gulch (T. 13 I.., R. 39 E.). The flow has a distinctive chemistry (Brock and $G=0 I i \in I, 1973$, nos. 70-B-199 and 70-B-237; T. L. Hiright and D. A. Stanson, urpub. data) and contains phenocrysts of plabioclase and clinopyroxene iess than $5 \mathrm{~mm}$ in diareter. Phenocryst distribution is quite irregular. lisximum thickness is atout $50 \mathrm{~m}$; averase, asout $10 \mathrm{~m}$. Incluies three snall (less than $5 \pi$ in dianeter), columan-jointed knoks solith of Eltopia in T. $11 \mathrm{li} ., \mathrm{R} .30 \mathrm{E}$. (size espresered on map); these knobs are surrounded by sand and ray be glaciel erratics, but theix rorthnorthwest alinement parallels the trer:i of aikes, suggesting the remote possibility that the knobs are croded pluglike bodies protruding ahove younger flows. Tre largest (northerniost) of these knobs was cestrojel by a bulldozer in 1975. liormal paleonagnetic polarity

IlTTFACAlYYOA ERSALT-Cne or more intracaryon Flchs of plagioclase-fhyric (come phenoamysts as large as $1 \mathrm{~cm}$ across) basalt occurring as isolated remninis along the ancestral Sneire fiver Canyon in the Devils Canyon-stootum Canyon area, 3 kn upsireail Iron Central Ferry

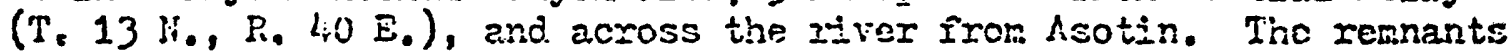
all have major elenent compositions similar to the Frenchman Spmins chomical tjue (irigint and others, 1973) but differ in trace elcments (J. S. Fruchter, ixitten comun. 1975) ard Sr-isotope ratios (Nélion and others, 1975). The paleonagretic polarity apparentiy varies fron reversed to transitionsl betrecn rements, nexhajs indicating rore then one a.je of extrusion (S. R. Choiniere, writien cormun., 1975). Thiciest flo: remant is about $60 \mathrm{~m}$ in Devils Canyon

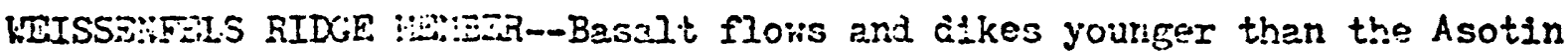
liemks and oluer than tho Eloping Yountain liember in and south of tho lewiston Easin. !ion:el jalecmagnctic polarity. Divicidi into two infoman? units

Easalt of Slfprery Creci:-Easalt flo: or Ilows and feeder dike south of Asotin. Chicracterlzad by small pliojoclase phencerysts ( $3 \mathrm{am}$ or Iess

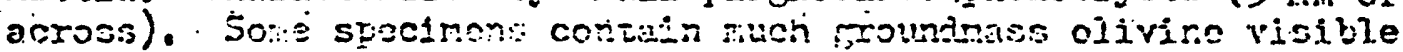

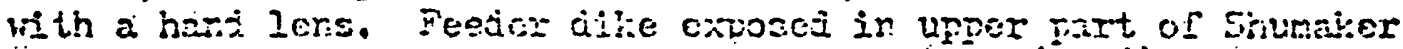

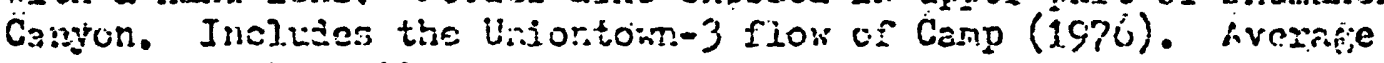
ti:Ickness, al.iut 10 :!: 
Basalt of Lewiston Orchards--Uppermost flow or flows south of Lewiston. Rather cozrse grainot and sparsely plagfoclase phyric; phenocrysts are raxely as large as $1 \mathrm{~cm}$. Olivine visible in hand specinen. Avorage thickness, 10-15 $\mathrm{m}$, but $37 \mathrm{~m}$ thick along Thane Road between Lewiston and Leiriston Orchards. Probablo feeder dikes exposed on Weissenfels Ridere

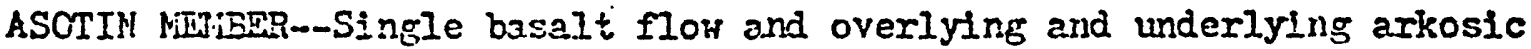
sedimentary deposits. Occurs chicfly in the Leriston Basin, where the haclily jointed flow conmonly forms prorinent cliffs. On the Uniontom Flateau, the flois is poorly exposed but seens to fill and spjil out of a valley of the ancestral Union Flat Creek. A . small outcrop south of lind ( $T .17 \mathrm{~N} ., \mathrm{R}_{0} 33 \mathrm{k}$. ) may lie along the western extcnsion of this ancestral valley. The flow contains sligintly rore $\mathrm{MgO}$ and $\mathrm{Al}_{2} \mathrm{O}_{3}$ and less $\mathrm{FeO}$ than the Ponona Member (Camp, 1976) ard has nomal paleomagretic polarsty. In the Ieviston Basin, the flow occurs nearly everywhere in invarive sill-like relation with the sedinentary rocks. The top of the rlow is peperltic and chilled ascinst the seiinentary deposit, which at the time of oruption was ron-indurated and quite thin, as aerolynamically-shaped ejecta are sprinikled through the deposit. Similar occurrences in the Pomona sember and older flows were described by Schmincke (1967b). The Ia-ker arerases 60-70 $\mathrm{n}$ thick, with the flot! about half the total ti:iciness

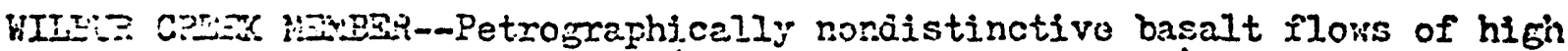
$\because$ O Yari=a chenical type (Vrigit and others, 1973). Occurs on the ïicntown Flatezu; in a small area $5 \mathrm{kn}$ west of Cow Creek (T. $16 \mathrm{~N}$. , R. 35 ard 37 E.) interpreted as a valley-filling; ard in the northrest corner of rap area botween Warden and Othollo, where it fills a sinuous rimmon caryon (Grulier, 1955, p. 106-107: Grolier and Bineliam, 19?:). A.Iso occuns in the Iaviston Easin (the Uniontom-2 flow of $z=-2$ [19?5]) but is too thin to sap seraratoly. Includes underlying. tin:s secinentary dcposits in the weriston Besin and locally on the ijsontoin Platezu. Jorgal paleomagnetic polarity. Average thicloness zess ther $20 \mathrm{li}$. Easalt was prosunably empipted in or east of the eastamn fart of the unap area ard flowed west in ancestral valleys, which in plazss hive a distinct aeronagnetic signature (Stanson ard otiars, 19?_). Forms part of the Uniontorn flows cr Syanson and others $(1975 \mathrm{~b})$, iho interpreted clongate outcrop pattern on Uniontorin Plateau to refleat construcional high along a linear vent systen or a valley betreen. two such systens

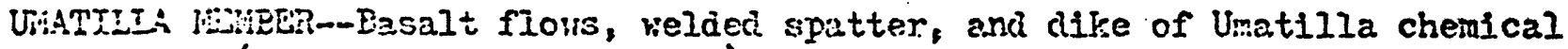
type (liright and others, 1973). Very fine grained and sparseiy Fiagioclass fiyric. Occurs in rastern and southwest parts of map arca. Fresent in the Ireriston Basin but too thin to map separately. Equivalent to the Uniontorn-1 flow of Canp (1970) and the "Fuffer Butte Flows" of Gibson (1960). Normal falcoingnetic polarity. Thiclencss as Frest as $200 \mathrm{~m}$ at fuffer Butte, averatios iboul $50 \mathrm{~m}$. Vent for at least sons of nember cefincd by dire, velded spatter, and thick pile of fiows at and soltin of Yuffer Rutte (T. ? N., R. 45 E.) Inciudes liviorlying thin sedireniary deposits in the Leviston Pesin, Grande lionie Valley, and on tho southern Uniontoun PJ.steau. Also inciules viterlyng thin "andosite" flor (Brots and Golter, 1973. Tavi.cs 3-t. and 3-2, no, DSTi71-73) at heed of Yakarawe Canyon (sec.

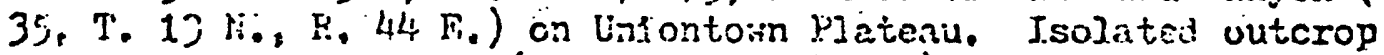

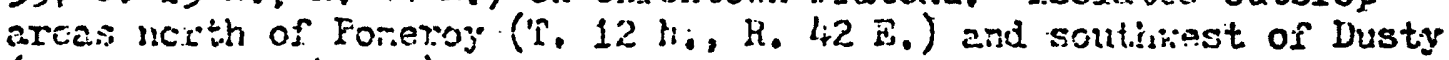
(T. 1; i., R. lil E.) t,citative]y cousidorel rennants of vallej-filling

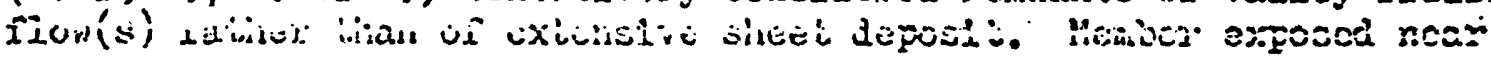


mallin lisp continiously traceable to type locality renr lieiary Dan (Schatncie, 1967a), and it was recognized during drillints beneath the Halla Walla Basin, 8 ksil southwest of College Flace (Bush and others, 1973)

WILBUR CREAK AND UHATILIA HEMPBRS, UNDIFFEREITIATED--Shorm only where thickness of either nember alone is too small to show

BASALT OF EAGIE IAKB--Basalt flow underlying Pomona Kember and overlying Priest Rapits liember in vicinity of Eagle and Scooteney Lakes (T. 14 H., R. 29 and 30 E.). Scattered plagloclaue phenocrysts less than $5 \mathrm{~min}$ across. Normal paleonagnet1c polarity. Chemistry. variable but within the range of the Huntzinger flow of liackin (1961) as 1niterpreted by Ward (1976). Intersertal and intergranular texiure, not: diabssic as is some reported Huntzinger (Ward, 1976). Cozzelation rith Huntzinfer is likely; if so, flor is probably younger than Vilbur Cresi Henber and older than Esquatzel Member, as ceduced from sturies of core from drill holes on the Hanford Resezvation (C. H. Hyers and R. K. Ledgerwood, oral comnun., 1976)

\section{YAISAPUI PASAIT}

PRIES: S:PIDS IERIRR-Basalt flows and dikes that, in map area, are of Lolo chenical type (Wright and others, 1973) and have reversed jaiecrasnetic pjlarity. Typified patrographically by scattered plestoclase phenocrysts generally leas than $5 \mathrm{~nm}$ but rarely up -o $1 \mathrm{~cm}$ long ari olivine phenocrysts .5-1 $\mathrm{mm}$ in diameter. Includes Fow and underlying 8 n-thicis tufiaceous siltstone and claystone resiing on extensive Pricst kapids flow $3 \mathrm{~km}$ north-northeast of Colfax elons liz stivey 195. This upper flow is of high-lig Lolo che-ical type, as is dilie at Pullman. Also includes bedded tephra sixed with arics:s detritus below a flow at a vent area on the easi edse of Paicuse (T. 16 N.., R. 46 E.). Block with chillea $=3 x$ ins in tepinza derosj.t hes unusulal low $\mathrm{Fe}$ and high $\mathrm{Tl}$ and $\mathrm{lla}$ oofostion. lienber occurs as extersive flow or flosis (generally. cily one floi: 1s present at a Eiven losality) across north part of iñ area. Averase thickness, 30-40 n. Only known dikes of similar coiposition are east of map area. Hlows presumebly wore fed by these alies and Ilored westwaid to the central. Columbia Plateau as broad shestfloods. Ease is comionly pillowed. Chemlcally equivalent to tise uppermost Eriest Rapids near Sentine]. Gap west of nap area as defined by liactin (1961). Tentatirely identified by Bush and others (1973) in drill cuttings from a hole near College Flace in the Ville Halla Basin. Equivilent to scne of Bond's (1963) Lolo Creek. flor. One of the nost inportant marier untts on the Columila. Dlatcall.

FOZA Hi:R-Eass?t flows, minor arount of tephra, and dikes of Frenchman Spungs chenicul type (Hrient and others, 1973; they assiened the Rowe to its om chemical type, but subsequent work demonstrates the equivalency of the trio types) that are consistently jularioclase phyrf.c. Flous contain several pircent of single, only rarely clotted, phenocrysts avesustre nealy $1 \mathrm{~cm}$ scross. Fhenocrysts are evenly distuluted. Includes several retcrs of sariolite and sedimentary. roclis beneath :ozio flows in mariy eastern outcrops where lirenchuan: Sjinges licmise i= ahsent, Throughout nost of arch, crinsists of one. cr: tho 17ens, but locally, espec! tlly near vents, several thin flans aro piefent. Some flows diatingished bj cifferenses in phetrocryst sine, abundaries, or both. Flows were cruptesi from a. 
Basalt of Dolse--ihere mapped, nearly everythre forms the hasel flow (locally; two or r:ore flohs) of rember. Includes feeder dikes in Blue Nountains and Grande Ronde Valley. Stippled where overlain by flows of Frenchnan Springs chemical type. Distinctive coarsegrain size causes Erusy weathering, especially at lok elevations. Rich in altered olivire. Scattered large plagioclase phenocrysts up to $2 \mathrm{~cm}$ long. Chenically distinctive (Griggs, 1976, table 4, nos. 10 and 21 and text; Brock and Grol.ier, 1973, tables 3-A and 3-B, no. DSTif 71-57). Hornal paleonajnetic polarlty. Dodge-type flow's comonly overlie and are overlain by saprolite, indicating eruption durirg a period of weathering after cessation of most Grande Ronde Basalt eruption. In Benjamin Gulch south of Pomeroy (i. $11 \mathrm{li}, \mathrm{R}_{.} 42 \mathrm{E}$ ) saprolite is nissing and flows of Dodge, Frenchran Springs, and Yairina cherical types are intoriodded, suggesting intertonging of Harepur and Grande Ronde Basalt. This is the only locality inere such intertonguird was recognized. From Clearwater Ranjer Siation (T. 8 I.., R. 42 E.) to south edge of map area, the Doije floi:s are locally overlain by an untapped flow o: distinctive composition (ihe informally nansd George Creek flow) but no flows of Frenchian Springs chemical type. (See Camp [1976]. who assigned the George Crees flor to what is now called the Grande Ronde Basalt before its relation to the Dode was clarified). At one mapped locality ( $5 \mathrm{kn}$ kest of Bif Butte, T. $7 \mathrm{H} ., \mathrm{R}_{0} 44 \mathrm{H}$ ), unit includes cily the George Creek flok, which is here overlain by the Roza hembar. s-iall exposure of Dodice-type flout at base of Frenchnan Springs section rarth of Shorfler (T. 11 i., R. 33 E.) sugfests possibility of connection bansath Bureka Flat and Touchet River Valley to mapped Dodge near ilalla Walla

Bisalt of Robinefte lountain--Distinctive aphyxic, dilstytaxitic, iddingitized-olivine kasalt south of Dajton. Includes feeder ditee exposes alcing East for: of Touchet hiver. Stippled where overlain by rloits of Frenciran'Spririgs chemical type. Chemically similar to younger. Asotin lifiber. Underlies Dodge flow at Ecleler llountsin (T. $9 \mathrm{~N}$, R. $40 \mathrm{k.}, \mathrm{miss}$.eljed on base reg); elsewhere directly underlies flows of Frenohran sirings tjpe hinerever overlying flows are present. Overliss saprojite dereloped cil Grande Ronde basalt. llormal paleoragnetic polarity

GRAYDS KO:DS LAS:TI--Das!lt flows, dikes, and minor deposits of tephra forming yrincipel farmation of the Elue rountains and the entire Colvinie Ylateau Irovince. Consists chicfly of aphyric, fins-greined, . fetrographicelly nonilstinet flor:s of Yakina chemical type, including its high lig and Ii ani loi lig subtypes (Hitight and others, 1973). Loczlly, a.s along Grancle Roncic Valley and north of Snaice River in Letiston Jasin, incluies several plarioclese-phyric flows low in the seaticn (urit $T_{\mathrm{r}} \mathrm{r}_{1}$ ). Single flows vary in thiciress from less than $1 \mathrm{~m}$ to nore than $50 \mathrm{si}$, and nost probubly eover several tens to several

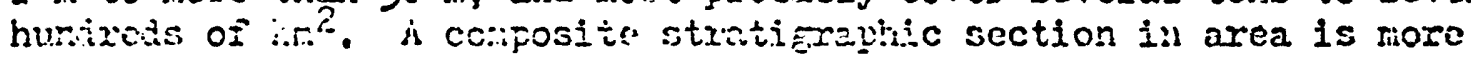

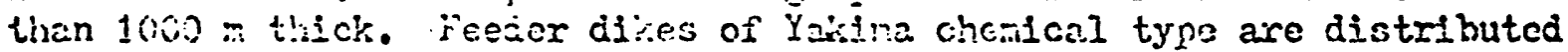
thro:l hont the cutcron area o: the Grance Ponde, and several vent arcis vere juted by the occur.: ne of veldent spattor. Tro casily accessible cyinte: are 1) at ilis junction of the Palouse hiver and

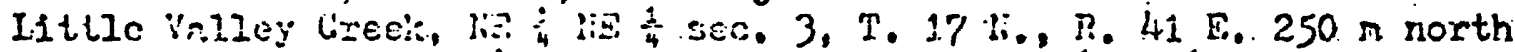

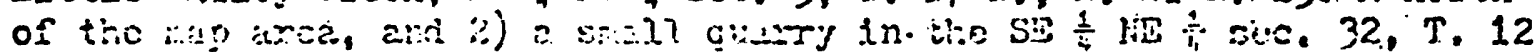

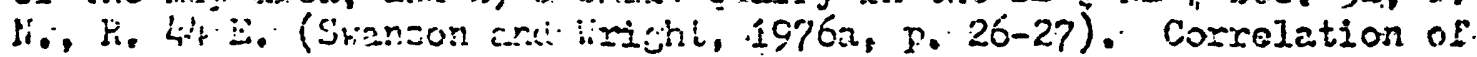

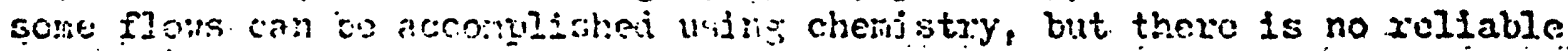
ficl: critezion knol on flon apearance. "he formation can be : 
narron linear vent syster defined by dikes, tephra deposits (including. welöed spatter) and relic cones, extending north-northwest across map area from T. $6 \mathrm{~N}$., R. $45 \mathrm{E}$. to T. $17 \mathrm{H} ., \mathrm{R}_{\text {. }} 39 \mathrm{E}$., a distance of more than $120 \mathrm{~km}$ (Binghem, 1970; Swanson and others, 19750). Flows advanced chiefly westiard from vents because of prevailing slope direction. A rubbly natural margin to a columnar Roza flow is exposed in sec. 35. T. 13 N., R. $44 \mathrm{~F}_{\text {. }}$ on the west edge of the Uniontorn Plateau (Halters arid Glancy, 1969), and a similar termination occurs along Asotin Creek in sec. 22, T. $10 \mathrm{H}, \mathrm{R}, \mathrm{R} .45 \mathrm{E}$. llost of the menber apparently . has transitional paleonagnetic polaxity (Rietman, 1966), but at least ons dike and perhaps ore flow in south part of arca have reversed polarity (S. R. Choiniere, written conmun, 1976). Average thickness in rap area is about $40 \mathrm{~m}$. Thickness generally increases from east to west, although irregular unciexlying topography strongly affects thickness 10:211y. Meinter apparently did not cover southwest part of nap area orisg: to a constructional topographic high in the underlying Frenchman Spi-nss Member. Hember is thin, less than $15 \mathrm{~m}$, in Grande Ronde Valley whereas younger units are relatively thick, suggesting that developnent of sirictural kasin began after Roza tine. Nenber is the key nariker unit across much of the Coluidia Plateau (íackin, 1961; Lefebrre, 1970)

FPEX:ZU: SERINGS IUWBER-Basalt flows, minor anount of tephra, and dikes, 213 of Frenchizan Springs chenical type (rright and others, 1973) except st:ere noted belo:. Incluies a saprolite, axkosic.sedimentary rocks, $c=$ both corronly cresent at its base; these deposit.s thicken eastward Ero: Iess then $20^{\circ} \mathrm{cm}$ in Devils Canyon to more than $15 \mathrm{~m}$ in places near. the easterm Iinit of outcrop, er.a are the lithostratigraphic and in part tise-stratisfaphic correlative of the Vantage Sandstone irember firther rest. $\because \equiv-j$ flows contain irregularly distributed, plagloclase Iinerecrysts uj to $5 \mathrm{~cm}$ across, but some are virtially aphyric and Iool: in the ficio like sone of the unoerlying Grande Ronde Pasalt. Flo:rs in the is iva part of the merber are, in many places, highiy Fibric and those in the midile and lixper parts less phyric, but exceptions are cornon. Basal flo: is commonly pillowed. Normal Faleonagnetic polarity. Henter progressively thickens hestrard frca its eastern margin to about $150 \mathrm{~m}$ arross the Snalee River from Sheirler (T. $11 \mathrm{k}, \mathrm{R}_{0} 33 \mathrm{k}$. ), owing to both a grcater number and thicluress of stngle flovs. Peeder dikes for flows of Fronchman Syrings chemical

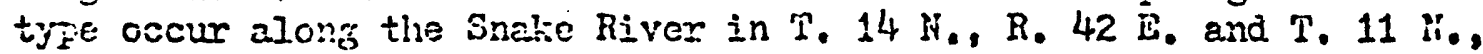
R. $33 \mathrm{E}$. and just soutin of the nap area in Oregon along Hill Creel: in $\mathrm{r} .6 \mathrm{H} . \mathrm{K}$. $33 \mathrm{E}$. A constructionel high in the member southrest of Sheffler sussests another source area. Upper flow at Godnan tilarigulation station (T. $7 \mathrm{~N} ., \mathrm{R} .30 \mathrm{E.}$ ) has Frenchman Sprines crenistry and is tentatively included in member. In places subdivided into three informal units, as follows

Easalt of Shefrier--liighly plo.gioclase-phyric flow, about 25 m in average thiclness, fed by di:e ir T. $11 \mathrm{~N} ., \mathrm{R} .33 \mathrm{E}$. Connection of dike and flow exposed on east side of Sraje fiver 
subdivided in the field into four magnetostratieraphic units on the basis of polarity deterinations using a portable fluxgate magnetoneter using the method of Swanson and Hright (1976b)

Nornal paleonagnetic polarity

Reversed paleomagnetic polarity

Normal paleomanetic polarity

Reversed paleomagnetic polarity

IKANAHA BASAIT--Baselt flows conformably underlying the Grande Ronde Basalt in soutineast part of r.ap area. Generally nediun to coarse grained. plazioclase-phyric with phenoerysts between 0.5 and $2.5 \mathrm{~cm}$ in length, and Exusy-weathering. Nomal paleomagnetic polarity in map area. Flow tiucknesses vary widely tecause of marked rellef on surface of older rocks. Chemically distinct from Grande Ronde flois (Camp, 1976)

lizs

i:zen

MizFrin
GRAYIIIC PCCKS--Includes quartz monzonite at Granite Point (Hooper and Rosenberg, 1970), a partiy exhured pre-basilt hill in the Snake River Canjon in T. 13 H., R. 43 E; tonalite at Bald Eutte (Hoffman, 1932), a steptos; and an unclassified granitoic rortheast of Pullman.

MTTA::S:HIC ROCXS--Vallier and Hooper (1976) indicate that this unit includes slizhtly metarorpiesed ilyscilite mudstone and sandstone of the Jurassic Coon Hoilow Formation; argillite and limestone of the upper. Triassic. Hurwal ard fiartin Exicge Formstions; retavolcanic, volcaniclastic, and clastic sedimentary roci:s of the upper Trlassic Doyle Creek and Hild Sheep Creek Formetions of the Seven Devils Group; and unmetamorphosed quartz dionite of probajle late Jurassic or Cretacaous are. Eyposed along Sralie Siver in southeast corner of nap area

MITA:CRTHC KOCKS-Includes isolated outcrop of sheared and mineralized quartaite in heajiaters of lienatchee Creek (T. 7 H., R. $43 \mathrm{E}$. ) ano four small areas of sheared, faulted, and locally mineralized argillite, Greenstone, quart:ite and oliextitic mstesedimentary rocks, amphibolitic schist, phyllite, netagabbro, and plegiogranite in Tucannon River drainsze, T. 8 and 9 \%., R. L1 E. (Kuntting, 1942). Age unknom, but Iitholejies are similer to the pre-lovex Permian "basement" rocks of Vallier and Hoofer $(1975)$ in lells Canyon

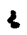

EELT SUFPRBROUP--Quertzic and retasiltstore in steptoes and exhumed prebasalt hills in northeast coiner of map. Apparently largely unaffected by the strong penetrative defortation and metamorphism shown by unit HzPan in the Hive liountains uplift 
Binghan, J. W., 1970, Several probable source vents for the Roza and Priest Rapids type basalts in Whitman and Adams Counties, Washington, in Gilmour, E. H., and Stradling. Dale, eds., Proc. Second Colunbia River Basalt Symposium: Cheny, East. Wash. St. Coll. Fress, p. 171-172.

Bond, J. G., 1963, Geology of the Clearrater embayment: Idaho Bur. Mines and Geology Famph., no. 128,83 p.

Brock, M. R., and Grolier, M. J., 1973, Chemical analyses of 305 basalt sazples from the Columbia hiver Plateau, Washington, Oregon, and Idaho: U.S. Ceol. Survey Open-file Repi., $35 \mathrm{p}$.

Brown, R. E., and NcConiza, M. H., 1900; Some contributions to the stratiGrephy ard indicated deformation of the Ringold Formation: Northrest Seience, v. 3t, p. 43-54.

Bush, J. H., jr., Morton, J. A., Anderson, J. V., Crosby, J. W. III, and Sisns, B. A., 1973, Test-observation rell near Valla Valla, Washington: Descivtion, stratierapinic reletionships, and preliminary results: hisi. St. iniv. College of trigineering Fept., 73/15-65, 38 p.

Camp, $\forall ., 1076$, Petrochemical stratigrephy ard structure of the Coiurija Fiver basalt, Lemiston Zesin area, Idaho-Washington: Ph.D. i-ss., Wasi, State univ., Fuliman, $201 \mathrm{p}$.

Flint, R. F., $\$ 933$, Orisin of the Cheney-Palouse scabland tract, Washington: Geol. Soc. Smerica Eull., v. 49, p. 461-523.

Gibsor. I. I., 1969, A comparative account of the flood basalt volcanism o: the Columbia Flateau ard easterm Iceland: Bull. Volcanologicue, v. 33 , p. $420-437$.

GrizEs, A. B., 1976, The Colurbla river Easalt Group in the Spokane Gueirangle, Washington, Idaho, and Vontana: U.S. Geol. Survey BulI. $14: 3.39 \mathrm{p}$.

Groliex, Y... J., 1965, Geology of part of the Big Bend area, in whe Colunbia Flateau, Hashington: Fi.. D. Diss., Johns Hopkirs Univ., \& Baztinore, $267 \mathrm{p}$.

Grolier, H. J. and Binghen, J. H.s 1971, Geologic map and sections of perts of Grant, Adans, ard Franilin Counties, Washington: U.S. Geol. Survey Hisc. Csol. Iny. liap I-559, scale 1:62,500.

Holz: R. T., Wrj.ght, T. L., and Swanson, D. A., 197, Petrogenetic simificarce of cher:ical trends in the youngest unit of Yalcima iatelt on the Columbia Platsau, routhrest U.S.A.: EuIl. Volcarologique (in presis).

Hoffran, H. G., 1932, The geology of Beld Butte lidge, Hashington; Jour. . Geol., v. 40,2 . $63,4-550$. 
Hooper, P. R., and Rosenberg, P. E., 1970, The petrology of Granite Point, southeastern Wishington: liorthrest Sci., v. 44, p. 131-142.

Huntting, H. T., 1942, Geology of the midale Tucannon area: M.S. Thesis, Wash. Stzte Coll., Lullman, $33 \mathrm{p}$.

Lefebvre, R. H., 1970, Colunbia River basalts of the Grand Coulee area, in Gilnour, E. H., and Strailing, Dale, eds., Proc. Second Columbia River Easält Sympoziun: Cheney, East. Wash. St. Coll. Press, p. 1-38.

Lupher, R. L., and liarren, $W . C ., 1042$. The Asotin stage of the Snake hiver canyon ncar Lewiston, Idaho: Jour. Geology, v. 50, p. 865-831.

Mackin, J. H., 1961, A stratigraphic section in the Yal:ima Basalt and the Ellcrsours Forration in south-central Weshington: Wash. Div. Mines and Geolosy, Rept. Inv. 19, 45 p.

Mckee, E. H., Swanson, D. A., and kiright, T. I., 1977, Duration and volume of Collubia River dasalt volcanisin, Washington, Oregon, and Idaho:

Geol. Soc. America Absts, with Frograms, v. 9, no. 3, p

Myers, C. H., 1973, Yarima Basalt Ilowis near Vantage, and from core holes in the Pasco Basin, Hashington: Fh.D. Diss., Uaiv. Calif., Santa Cruz, $147 \mathrm{p}$.

Nelson, D. O., Swarson, D. A., and Wright, T. I., 1976, Strontium isotopic ccrposition of jrtracanyon flows of Yajina Basalt, southeast

Vashington: Geol. Soc. Arerica Absts, with Prograns, v. 8, no. 3, po 399.

Rietman, j. D., 1966, Remenent rafsetization of the late Yakina Basalt, Hashington State: Eh.D. Diss., Stanford lniv., Stanford, Ca.lif., 87 p.

Schmincie, H.-U., 185\%, Stratigraphy and petrosraphy of four upper Yakima baselt flows in south-central Heshington: Geol. Soc. Ameriça Bulf.t v. 78 , p. $1335-1422$.

Schmincine, H.-U., 1967b, Fused turf and pépórites in south-central Hashingtion: Geol. Soc. Amsxica Bu?I., v. 78, p. 310-330.

Swanson, D. A., and Wright, T. I., 1976a, Cuide to field trip between Fasco erd Pullian, hashington, emphasizing stratigrephy, vent areas, anj intracarjo: flows of Yalrine Easalt: Geol. Soz. Anerica Cordill. Sect. litg., Pullman, Hasin., Field Guide Ho. 1, 33 \%.

Swanson, D. A., and irisht, T. I., 19765, Ragnetostrationaphic units in the Yarima Basalt, southeast Hashington: Geol. Soc. America Aists. with Frograns, v. 8, no. 3, p. $413-414$.

Swasson, I). A., Hright, T. I., end Clen, Richard, 1975a, Intracanyon flows of Yurina Eiselt along the Snakc Hiver, southeast Washington:

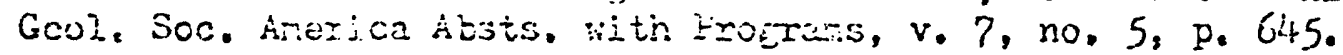

Swarison, D. A., irifit, T. I., and Heir, R. I', 19750, Jinear vent systens a:d estinatci rates of resca proluction and erurition for the Yalina Easalt on the Coluntia FlEteau: Aner, jour. Sci., v. 27.5 , p. $8,77 \div 505$.

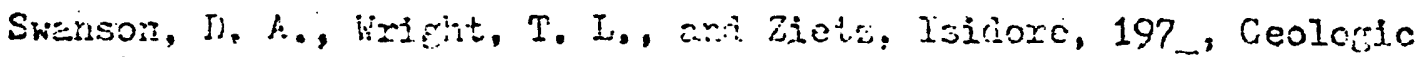

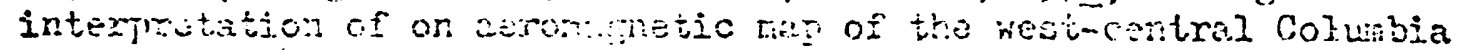

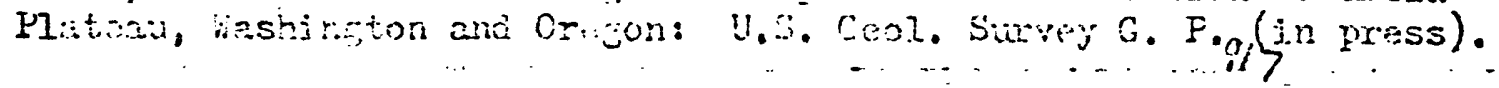


Swainion, D.A. and others, in press, Revisions in stratigraptic nomenclature of the Columbia River Basalt Group: U.S. Geol. Survey Bull.

Vallier, T. L., and Hooper, P. R., 1976, Geologic guide to Hells Canyon, Snake River: Geol, Soc. America Cordill. Sect. Mtg., Pullman, Vash., Fleld Guide Ho. $5,38 \mathrm{p}$.

Halker, G. :..,1973, Contrasting compositions of the youngest Columbia River basalt flows in Union and Halloria. Counties, liortheastern Oregon: Geol. Soc. Arerica Bull., v. 84; p. 425-430.

Walters, $\dot{y}$, I., and Glency, P. A., 1969, Recomnaissance of geology and of Eround-water occurrence in Hhitman Counity, Vashington: Wash. Depi. Water Resources Hater Supply Bull. 26, 169 p.

Ward, A. N., II., 1076, Chemistry and petrology of the Huntzinger flow, Colunbia Piver basalt, Hashington: Geol. Soc. Anerica Absts. with Frojrams, v. E, ro. 3, p. 418-419.

bright, T. I., Grolier, M. J., and Sranson, D. A., 1973, Chemical variation related to the siratigraphy of the Columbia River hasalt: . Geoi. Scc. Anerica 3ull., v. 84, po 371-336. 